\title{
DAMPAK SEKOLAH LAPANGAN GOOD AGRICULTURE PRACTICES (SL-GAP) TERHADAP PENINGKATAN PRODUKSI DAN PENDAPATAN PETANI DALAM USAHA TANI BAWANG MERAH (ALLIUM SATIVUM L) DI KECAMATAN BADAS KABUPATEN KEDIRI
}

\author{
Tuban $^{1}$, Jadi $^{2}$ \\ ${ }^{1}$ Balai Besar Pelatihan Pertanian Ketindan Jl. Ketindan No. 1 Kelurahan Ketindan Kecamatan Lawang \\ Kabupaten Malang Provinsi Jawa Timur \\ ${ }^{2}$ Dinas Pertanian dan Pangan Kabupaten Blitar, Jl. Ahmad Yani No. 25 Sananwetan Kecamatan Kepanjenkidul, \\ Kota Blitar Jawa Timur
}

Koresponden Email: tuban1968@gmail.com

\begin{abstract}
Abstrak
Penelitian ini dilakukan untuk mengetahui dampak kegiatan sekolah lapang terhadap peningkatan keterampilan, produksi dan pendapatan petani bawang merah di desa Sekoto, Kecamatan Badas kabupaten Kediri. Metode penelitian yang digunakan dengan menggunakan metode diskriptif Analisis,sampel yang digunakan adalah sample yang ditentukan (purposive sampling), yakni 60 orang responden yang terdiri dari 30 responden alumni SL-GAP dan 30 orang tidak mengikuti SL-GAP. Hasil penelitian menunjukkan bahwa pada responden yang mengukiti SL-GAP produksi bawang merahnya mencapai sebesar 45.9 ton / ha dengan pendapatan mencapai Rp 23.833,-/Gg sedangkan kelompok yang tidak melaksanakan SL mencapai produksi bawang sebesar 23.6 ton / ha dengan pendapatan Rp 17.700,-/ kg. Hal ini menunjukkan bahwa terdapat hubungan yang signifikan antara tingkat penerapan teknologi usahatani SL-GAP bawang merah dengan produktivitas dan pendapatan bawang merah.
\end{abstract}

Kata kunci : Dampak SL GAP, Peningkatan Produksi, Pendapatan Petani

\begin{abstract}
This research was conducted to determine the impact of field school activities on the improvement of skills, production and income of shallot farmers in Sekoto Village, Badas District, Kediri Regency. The research method used is descriptive analysis method, the sample used is a sample that is determined (purposive sampling), namely 60 respondents consisting of 30 respondents who are SL-GAP alumni and 30 people who do not follow the SLGAP. The results showed that the respondents who cut the SL-GAP production of shallots reached 45.9 tons / ha with an income of Rp. 23,833, - / kg while the group that did not implement FFS achieved onion production of 23.6 tonnes / ha with an income of Rp. 17,700/ kg. This shows that there is a significant relationship between the level of application of onion SL-GAP farming technology with the productivity and income of shallots.
\end{abstract}

Keywords: Impact Of SL GAP, Increased Production, Farmer Income

\section{PENDAHULUAN}

Bawang merah merupakan salah satu komoditas sayuran unggulan yang sejak lama telah diusahakan oleh petani secara intensif. Komoditas sayuran ini termasuk ke dalam kelompok rempah tidak bersubstitusi yang berfungsi sebagai bumbu penyedap makanan serta obat tradisonal. Komoditas ini juga merupakan sumber pendapatan dan kesempatan kerja yang memberikan kontribusi cukup tinggi terhadap perkembangan ekonomi wilayah [1]. Produksi bawang merah nasional sampai saat ini masih terpusat di beberapa kabupaten di Pulau Jawa seperti Kuningan, Cirebon, Brebes, Tegal, DOI: https://doi.org/10.55127/ae.v15i2.100
Pemalang, Nganjuk, dan Probolinggo [2].

Dalam upaya pemenuhan kebutuhan akan produksi bawang merah yang lebih kompetitif, diperlukan upaya peningkatan produksi yang mengacu pada peningkatan efisiensi baik ekonomi, mutu maupun produktifitas melalui penerapan teknologi mulai dari penentuan lokasi, penanganan benih, penanaman, pemeliharaan, hingga penanganan panen yang tepat. Perkembangan luas panen, produksi, dan produktivitas bawang merah tahun 2009-2013 seperti tertera pada Tabel 1. 
Tabel 1. Perkembangan Luas Panen, Produksi dan Produktivitas Bawang Merah di Indonesia Tahun 2009 - 2013.

\begin{tabular}{lccr}
\hline Tahun & $\begin{array}{c}\text { Luas Panen } \\
(\mathrm{Ha})\end{array}$ & $\begin{array}{c}\text { Produksi } \\
\text { (Ton) }\end{array}$ & $\begin{array}{c}\text { Produktivitas } \\
\text { (Ton / Ha) }\end{array}$ \\
\hline 2009 & 104.009 & 965.164 & 9.28 \\
2010 & 109.634 & 1.048 .934 & 9.57 \\
2011 & 93.667 & 893.124 & 9.54 \\
2012 & 99.519 & 964.221 & 9.69 \\
2013 & 98.937 & 1.010 .773 & 10.22 \\
Rata - Rata & 98.686 & 934.092 & 9.46 \\
\hline Sumber $:[2]$ & & &
\end{tabular}

Setiap tahun hampir selalu terjadi peningkatan produksi bawang merah, akan tetapi hal tersebut belum mampu mengimbangi peningkatan permintaan bawang merah secara nasional seiring dengan bertambahnya jumlah penduduk dan berkembangnya industri olahan. Berdasarkan data dari [3], produksi bawang merah kabupaten Kediri dari Januari sampai dengan Desember 2018 dalam ton/ha disajikan pada Tabel 2.

Tabel 2. Produksi bawang merah provinsi Jawa Timur

\begin{tabular}{llc}
\hline No & Bulan & Produksi (Ton) \\
\hline 1. & Januari & 6.602 \\
2. & Februari & 5.016 \\
3. & Maret & 3.166 \\
4. & April & 2.437 \\
5. & Mei & 4.151 \\
6. & Juni & 10.726 \\
7. & Juli & 19.665 \\
8. & Agustus & 11.618 \\
9. & September & 15.337 \\
10. & Oktober & 13.618 \\
11. & November & 15.938 \\
12. & Desember & 4.394 \\
Jumlah & 112.668 \\
\hline \multicolumn{2}{l}{ Sumber: $[3]$} &
\end{tabular}

Melihat perkembangan produksi bawang merah di kabupaten Kediri sering terjadi fluktuasi, maka perlu upaya peningkatan produksi secara konsisten dan kontinuitas. Dengan itu diperlukan ketrampilan petani dalam peningkatan produksi bawang merah, salah satunya dengan mengunakan metode Sekolah Lapangan GAP Budidaya bawang merah.

Umbi bawang merah, khususnya yang memiliki karakteristik kualitas seperti bawang impor (super), yaitu umbi besar (diameter 2,5-3 $\mathrm{cm}$ ), bentuk bulat dan warna merah, mempunyai prospek pasar yang sangat baik di pasar domestik maupun ekspor. Permintaan pasar dalam negeri terus meningkat dari tahun ke tahun. Pada tahun 2015, kebutuhan bawang merah diproyeksikan mencapai 1.195.235 ton. Jika produktivitas bawang merah diproyeksikan mencapai 10,22 ton/ha, maka dibutuhkan sekitar 116.950 ha areal panen. Mengacu pada areal panen tahun 2012, yaitu sebesar 99.519 ha, maka pemenuhan kebutuhan bawang merah tahun 2015 memerlukan perluasan areal panen sekitar 17.432 ha atau sekitar 6.000 ha per tahun. Sasaran produksi sebesar 1.195.235 ton tersebut pada tahun 2015 termasuk untuk benih bawang merah sekitar 102.900 ton [4]. Proyeksi kebutuhan bawang merah sampai dengan tahun 2025 tertera pada Tabel 3.

Dalam kurun waktu tiga tahun terakhir (2011-2013) terdapat indikasi kuat bahwa daya saing bawang merah nasional terus menurun dibandingkan bawang merah impor. Kondisi ini diperparah dengan semakin tingginya selisih harga satuan bawang merah ekspor dan impor terkait gejolak nilai rupiah terhadap dollar Amerika Serikat. Jika kondisi perbedaan harga ini semakin tajam, maka diperkirakan pada tahun-tahun mendatang pun impor bawang merah akan terus menekan produksi dan harga bawang merah nasional. Pada akhirnya, hal ini dapat menurunkan motivasi petani untuk menanam bawang merah dan produksi bawang merah sehingga akan meningkatkan ketergantungan terhadap bawang impor seperti tertera pada Tabel 4. 
Tabel 3. Proyeksi Kebutuhan Bawang Merah untuk kebutuhan Konsumsi, Benih, bahan Industri dan Ekspor periode 2017 - 2025.

\begin{tabular}{crrrrr}
\hline & \multicolumn{5}{c}{ Kebutuhan (Ton) } \\
\cline { 2 - 6 } Tahun & \multicolumn{1}{c}{ Konsumsi } & \multicolumn{1}{c}{ Benih } & Industri & Ekspor & Total \\
\hline 2017 & 994.378 & 104.900 & 40.000 & 105.000 & 1.244 .278 \\
2018 & 1.022 .751 & 105.900 & 45.000 & 105.000 & 1.278 .651 \\
2019 & 1.038 .092 & 106.900 & 45.000 & 110.000 & 1.299 .992 \\
2020 & 1.067 .527 & 107.900 & 50.000 & 110.000 & 1.335 .427 \\
2021 & 1.083 .540 & 108.900 & 50.000 & 110.000 & 1.352 .440 \\
2022 & 1.114 .077 & 109.900 & 55.000 & 120.000 & 1.398 .977 \\
2023 & 1.130 .788 & 110.900 & 75.000 & 125.000 & 1.441 .688 \\
2024 & 1.177 .179 & 111.900 & 75.000 & 125.000 & 1.489 .079 \\
2025 & 1.194 .837 & 116.900 & 80.000 & 150.000 & 1.541 .737 \\
\hline
\end{tabular}

Sumber : [5]

Tabel 4. Perkembangan Eksport dan Import Bawang Merah Tahun $2007-2012$.

\begin{tabular}{rrr}
\hline \multirow{2}{*}{ Tahun } & \multicolumn{2}{c}{ Volume (Ton) } \\
& \multicolumn{2}{c}{ Import } \\
\hline 2007 & 9.357 & 107.649 \\
2008 & 12.314 & 128.015 \\
2009 & 12.822 & 67.330 \\
2010 & 3.234 & 73.270 \\
2011 & 13.792 & 160.467 \\
2012 & 12.647 & 119.505 \\
\hline Sumber : $[6]$ & &
\end{tabular}

Peningkatan produksi yang lambat sementara konsumsi terus meningkat seiring dengan meningkatnya jumlah penduduk dan pendapatan menjadikan ketersediaan bawang merah untuk keperluan rumah tangga dan industri makanan seringkali kurang dan hal ini mendorong naiknya harga komoditas tersebut. Sebagai tanaman musiman, puncak produksi bawang merah terjadi pada bulan-bulan tertentu, sementara konsumsi bawang merah hampir digunakan setiap hari dan bahkan pada hari-hari besar keagamaan permintaannya cenderung melonjak. Adanya perbedaan pola produksi dan permintaan menyebabkan terjadinya gejolak harga pada waktu tertentu, berupa lonjakan kenaikan harga pada saat permintaan lebih tinggi dari pasokan, atau harga merosot pada saat pasokan lebih tinggi dari permintaan [7]. Besarnya volume impor bawang merah, sebagaimana tertera pada Tabel 4 sejatinya menunjukkan bahwa masih ada peluang yang sangat besar untuk pasar dalam negeri. Usaha budidaya bawang merah memiliki prospek dan peluang usaha yang sangat baik di masa yang akan datang.

Dari sisi produktifitas, dalam tujuh tahun terakhir (2007-2013) rata-rata produktivitas bawang merah nasional hanya sekitar 9,46 ton/ha, jauh di bawah potensi produksi yang berada di atas 20 ton/ha. Beberapa permasalahan rendahnya produktivitas tersebut antara lain: (a) ketersediaan benih bermutu, (b) prasarana dan sarana produksi terbatas, (c) belum diterapkannya SOP (Standard Operating Procedure) spesifik lokasi secara benar. Sebagian petani yang hanya tergantung pada alam, tetapi ada yang berlebihan dalam penggunaan pestisida, kondisi ini menyebabkan tingginya tingkat residu pestisida yang pada akhirnya mengakibatkan tidak aman dikonsumsi serta pencemaran lingkungan. Oleh karenanya perlu ditangani lebih terarah untuk menghasilkan produksi dan mutu hasil yang tinggi serta ramah lingkungan. Untuk maksud tersebut usaha tani harus menggunakan teknologi maju dan dikelola secara professional dan efektif sejalan dengan kaidah Good Agriculture Practices (GAP).

Menghadapi tantangan dan tuntutan di atas, perlu adanya pembinaan melalui pelatihan petani yang mengusahakan bawang merah dalam penerapan teknologi budidaya yang baik (GAP). Sehubungan dengan telah berkembangnya sentra 


$\begin{array}{lll}\text { Info Artikel } & \text { Received } & : 14 \text { November 2021 } \\ & \text { Revised } & : 31 \text { Desember 2021 } \\ & \text { Accepted } & : 31 \text { Desember 2021 }\end{array}$

- sentra produksi bawang merah pada beberapa daerah, maka penerapan GAP tersebut harus diikuti dengan Standar Operasional Procedure (SOP), setiap komoditas yang bersifat spesifik lokasi. Penerapan GAP perlu dilengkapi dengan tersedianya SOP budidaya komoditas sebagai panduan petani dalam melakukan usahatani di lahan masing-masing. Buku SOP budidaya komoditas disusun bersama antara petani, petugas, praktisi dan pakar pada dasarnya merupakan petunjuk teknis baku yang bersifat spesifik (komoditas dan lokasi), jelas dan praktis dari setiap tahapan kegiatan. Penerapan budidaya berdasarkan GAP tersebut dilakukan melalui metode siklus pembelajaran petani secara langsung di lahan usahataninya dengan konsep Sekolah Lapangan (SL).

Sekolah Lapangan Good Agriculture Practice (SL - GAP ) merupakan salah satu pendekatan dalam meningkatkan pengetahuan, kemampuan dan ketrampilan petani tentang prinsip GAP melalui pola pembelajaran lewat pengalaman dengan menggunakan lahan sebagai tempat belajar. Melalui sekolah lapangan yang dilakukan setiap minggu sepanjang periode tanam, diharapkan petani dapat memantau pertanaman secara teratur sekaligus dapat mengkaji dan membahasnya sehingga menjadi ahli dan dapat mengambil keputusan sendiri. SL - GAP merupakan salah satu pendekatan dalam meningkatkan pengetahuan, kemampuan dan ketrampilan petani tentang prinsip GAP melalui pola pembelajaran lewat pengalaman dengan menggunakan lahan sebagai tempat belajar. (GAP adalah pedoman umum tentang budidaya yang baik dan benar melalui kaidah-kaidah yang memenuhi tuntutan konsumen dalam dan luar negeri menggunakan produk yang aman dikonsumsi, bermutu, dan ramah lingkungan. Untuk mempercepat penyerapan pengetahuan, ketrampilan dan sikap petani tentang budidaya bawang merah dikondisikan dalam kondisi senyatanya di lapangan dengan bimbingan seorang pemandu lapangan sebagai kelas belajar.

Berdasarkan uraian diatas tujuan penelitian adalah untuk mengkaji: a). peningkatan produksi bawang merah petani di Desa Sekoto kecamatan Badas Kabupaten Kediri setelah mengikuti SL - GAP budidaya bawang merah dan; b). Perubahan pendapatan petani bawang merah di desa Sekoto kecamatan Badas Kabupten Kediri setelah mengikuti SL - GAP budidaya bawang merah.
Jurnal Agrica Ekstensia

Vol. 15 No. 2 Tahun 2021

e-ISSN

\section{MATERIAL DAN METODE Tempat Penelitian}

Penelitian telah dilakukan di Desa Sekoto, Kecamatan Badas, Kabupaten Kediri. Penentuan daerah penelitian ini ditentukan dengan metode purposive (sengaja) dengan pertimbangan bahwa tempat merupakan sentra pengembangan bawang merah di Kecamatan Badas, Kabupaten Kediri.

\section{Sampel Penelitian}

Sampel dari penelitian ini adalah petani yang pernah mengikuti pelatihan SL - GAP bawang merah sebanyak 30 orang dan petani yang tidak mengikuti pelatihan SL - GAP bawang merah sebanyak 30 orang.

\section{Objek Pengamatan}

Objek pengamatan pada peneliitian ini adalah dampak pelatihan SL - GAP, yaitu dampak terhadap peningkatan produksi bawang merah dan peningkatan pendapatan petani bawang merah.

\section{Data Penelitian}

Jenis data yang diperlukan dalam penelitian ini adalah data primer dan data sekunder. Data primer dikumpulkan melalui teknik wawancara dengan menggunakan kuesioner yang telah disiapkan kepada petani responden yaitu petani bawang merah alumnus SL - GAP dan petani bawang merah non SL - GAP. Data sekunder diperoleh melalui studi pustaka dan juga laporan - laporan dari beberapa instansi pemerintah yang terkait yaitu dari Dinas Pertanian Propinsi Jawa Timur dan Dinas Pertanian Kabupaten Kediri.

\section{Analisis Data}

Untuk menguji apakah ada perbedaaan antara produksi dan pendapatan petani bawang merah alumnus SL- GAP dan non SL- GAP digunakan uji t independet. Jenis uji statistika ini bertujuan untuk membandingkan rata - rata 2 kelompok tani alumnus SL GAP dan non SL GAP yang tidak saling berpasangan atau tidak saling berkaitan. Tidak saling berpasangan dapat diartikan bahwa penelitian dilakukan untuk dua obyek yang berbeda yaitu dengan menggunakan analisis Uji $t$ untuk varian yang berbeda (unequal variance), menggunakan rumus Separated Varians : 


$$
t=\frac{\overline{\bar{y}}}{\sqrt{\frac{S_{1}{ }^{2}}{n_{1}}+\frac{S_{2}{ }^{2}}{n_{2}}}} \quad \ldots \operatorname{Pers}(1)
$$

dimana :

$\mathrm{X}_{1}=$ rata - rata (biaya, produksi, penerimaan, pendapatan dan produktivitas) petani alumnus SL - GAP

$\mathrm{X}_{2}=$ rata - rata (biaya, produksi, penerimaan, pendapatan dan produktivitas) petani non SL - GAP

$\mathrm{n}_{1}=$ banyaknya sampel alumnus SL GAP

$\mathrm{n}_{2}=$ banyaknya sampel Non SL GAP

$\mathrm{S}_{1}=$ standar deviasi petani alumnus SL GAP

$\mathrm{S}_{2}=$ standar deviasipetani Non SL GAP)

\section{HASIL DAN PEMBAHASAN Produksi Bawang Merah di Kabupaten Kediri}

Keberhasilan program-program pelatihan yang disebutkan di atas dapat diukur dengan melihat tingkat keberhasilan para peserta, dalam hal ini adalah petani bawang merah dalam menghasilkan produksinya. Jika produksi meningkat pasca pelatihan, tentu ada benang merah yang menunjukkan dampaknya. Namun, jika stagnan dan bahkan menurun, maka pelatihan yang telah dilakukan tidak memberikan manfaat bagi para petani. Dalam konteks Kabupaten Kediri misalnya, produksi bawang merah tahun 2014 sebesar 293,18 ribu ton, mengalami peningkatan sebesar 50,09 ribu ton $(20,61 \%)$ dibandingkan dengan tahun 2013 sebesar 243,09 ribu ton [8]. Perkembangan produksi bawang merah di Kabupaten Kediri dari tahun 2012 sampai dengan 2014, disajikan pada Tabel 4.

Tabel 4. Perkembangan Produksi (Ton), Luas Panen (Ha), dan Produktivitas (Ton/Ha) Bawang Merah di Kabupaten Kediri Provinsi Jawa Timur Tahun 2012-2014

\begin{tabular}{lrrrrrrr}
\hline \multicolumn{1}{c}{ Uraian } & \multirow{2}{*}{2012} & \multirow{2}{*}{2013} & 2014 & \multicolumn{4}{c}{ Perkembangan } \\
& & & & Absolut & \multicolumn{1}{c}{$\%$} & \multicolumn{1}{c}{ Absolut } & \multicolumn{1}{c}{ \% } \\
\hline Produksi (ton) & 222.861 & 240.087 & 293.179 & 20.226 & 9.08 & 50.092 & 20.61 \\
Luas Panen (ha) & 22.323 & 26.080 & 30.652 & 3.707 & 16.61 & 4.622 & 17.76 \\
Produktivitas (ton / ha) & 9.98 & 9.34 & 9.56 & -0.64 & -6.41 & 0.22 & 2.36 \\
\hline
\end{tabular}

Sumber Data : [8]

Berdasarkan Tabel 4, dapat dilihat bahwa terjadi peningkatan produksi bawang merah pada tahun 2012 sebesar 222.861 ton menjadi 240.087 ton pada tahun 2013, dan 293.179 ton pada tahun 2014. Walaupun peningkatan tersebut disebabkan oleh meningkatnya luas panen, yaitu 22.323 ha pada tahun 2012 menjadi 26.080 ha tahun 2013, dan 30.652 ha tahun 2014. Sementara produktivitas bawang merah mengalami penurunan, yaitu 9,98 ton/ha pada tahun 2012, menjadi 9,34 pada tahun 2013 dan 9,56 ton pada tahun 2014.

Kecamatan Badas di kabupaten Kediri termasuk salah satu Kecamatan pengembangan sentra bawang merah di Kabupaten Kediri Jawa Timur, dengan luas panen pengembangan pada tahun 2014 mencapai luas 1.707 ha, dengan produksi perhektar $128.271 \mathrm{Kw}$ [9]. Lebih lanjut gambaran luas panen dan produksi, khususnya komoditas bawang merah di Kecamatan Badas Kabupaten Kediri untuk 7 (tujuh) tahun terakhir tertera pada Tabel 5 sebagai berikut:
Tabel 5. Keragaan Luas Panen dan Produksi Bawang Merah Tahun 2008 - 2014 di Kabupaten Kediri.

\begin{tabular}{|c|c|c|}
\hline Tahun & $\begin{array}{c}\text { Luas Panen } \\
(\mathrm{Ha})\end{array}$ & $\begin{array}{c}\text { Produksi } \\
(\mathrm{Kw})\end{array}$ \\
\hline 2008 & 437 & 29.738 \\
\hline 2009 & 620 & 44.054 \\
\hline 2010 & 880 & 55.790 \\
\hline 2011 & 1.154 & 75.686 \\
\hline 2012 & 1.256 & 81.986 \\
\hline 2013 & 1.136 & 85.501 \\
\hline 2014 & 1.707 & 128.271 \\
\hline Jumlah & 7.190 & 501.026 \\
\hline Rata-rata & 1.027 & $\underline{71.575}$ \\
\hline
\end{tabular}

Pada Tabel 5 dapat dilihat bahwa luas panen bawang merah mulai tahun 2008 - 2014, ratarata seluas 1.027 ha, dengan produksi rata-rata sebesar $71.575 \mathrm{Kw} / \mathrm{ha}(7,1575 \mathrm{Ton} / \mathrm{ha})$, masih dibawah target standar produk yang akan dicapai dalam penerapan SOP Budidaya Bawang Merah Kabupaten Kediri sebesar $>10$ ton/ha (SOP 
$\begin{array}{lll}\text { Info Artikel } & \text { Received } & : 14 \text { November } 2021 \\ & \text { Revised } & : 31 \text { Desember 2021 }\end{array}$

Accepted : 31 Desember 2021

Budidaya Bawang Merah Kabupaten Kediri [3].

\section{Peningkatan Produktivitas dan Pendapatan Petani Bawang Merah}

Pada Tabel 6 disajikan peningkatan produktivitas bawang merah dan pendapatan petani bawang merah yang mengikuti SL - GAP dan yang tidak mengikuti. Berdasarkan nilai rata-rata dapat diketahui bahwa kelompok yang melaksanakan SL memiliki hasil produktivitas yang lebih banyak dibandingkan dengan kelompok yang tidak melaksanakan SL. Ratarata untuk hasil produktivitas antara kelompok yang melaksanakan SL sebesar 45,9 Kw/Ha sedangkan kelompok yang tidak melaksanakan SL memiliki rata-rata sebesar 23,6 Kw/Ha. Ada peningkatan produktivitas, yaitu sebesar 48,58\%. Tabel produksi Bawang merah hasil SL dan non SL sebagai berikut :

Table 6. Produksi dan pendapatanPetani Bawang Merah yang mengikuti dan tidak SL-GAP

\begin{tabular}{lcc}
\hline Petani & $\begin{array}{r}\text { Produksi } \\
\text { (Ton/Ha) }\end{array}$ & $\begin{array}{c}\text { Pendapatan } \\
\text { (Rp. Juta/ } \\
\text { Ha)) }\end{array}$ \\
\cline { 3 - 3 } $\begin{array}{l}\text { Alumnus SL - } \\
\text { GAP }\end{array}$ & 4,59 & 23.833 \\
$\begin{array}{l}\text { Non Alumnus } \\
\text { SL - GAP }\end{array}$ & 2,36 & 17.790 \\
\multicolumn{2}{l}{ Sumber: pengolahan data } &
\end{tabular}

Hal ini menunjukkan bahwa hasil produktivitas responden yang melaksanakan SL lebih tinggi dibandingkan dengan yang tidak melaksanakan SL. Peningkatan produktivitas disebabkan karena penggunaan teknologi SLGAP sehingga terjadi efisiensi dan efektifitas dalam penggunaan faktor-faktor produksi. Dimana dengan penggunaan input yang efisien dan efektif akan memberikan output atau hasil yang maksimal pula. Hasil penelitian ini sejalan dengan pendapat [10] yang menyatakan bahwa perubahan teknologi mengacu pada perubahan dalam teknik yang mendasari produksi atau produktivitas yang terjadi ketika suatu produk atau proses baru ditemukan atau suatu produk dan proses yang usang diperbarui. Dalam situasi seperti ini output yang sama dihasilkan dengan penggunaan input yang sama.

Dengan pengembangan teknologi di bidang pertanian seperti program SL-GAP ini diharapkan proses adopsinya akan cepat menyebar ke seluruh petani di Indonesia.

DOI: https://doi.org/10.55127/ae.v15i2.100
Jurnal Agrica Ekstensia

Vol. 15 No. 2 Tahun 2021

e-ISSN
Pendapat [11], mengemukan bahwa salah satu syarat mutlak pembangunan pertanian adalah adanya teknologi usahatani yang senantiasa berubah. Oleh sebab itu penggunaan teknologi dalam usahatani bawang merah sangat dibutuhkan oleh petani dengan harapan dapat meningkatkan produktifitas, meningkatkan efisiensi usaha, menaikkan nilai tambah produk yang dihasilkan serta meningkatkan pendapatan petani. Hal tersebut juga telah dibuktikan dari pendapatan penjualan bawang merah antara kelompok yang melaksanakan SL sebesar Rp 23.833.000,- sedangkan kelompok yang tidak melaksanakan SL memiliki rata-rata sebesar Rp 17.700.000,- atau terdapat kenaikan pendapatan sebesar $\pm 25 \%$. Hal ini menunjukkan bahwa harga jual bawang merah responden yang melaksanakan SL lebih tinggi dibandingkan dengan yang tidak mengikuti SL dengan kata lain kualitas bawang merah juga semakin meningkat. Hal yang sama juga disampaikan oleh [12] yang menyatakan bahwa dengan mengadopsi suatu inovasi oleh para petani, maka tujuan jangka panjang penyuluhan seperti better farming, better business, better living, dapat terwujud karena mengadopsi inovasi akan terjadi peningkatan produktivitas, selain itu juga peneran GAP telah sesuai dengan Standar Operasional Prosedur (SOP) mulai dari pemilihan bibit, pertanaman, pemupukan, dan pemeliharaan lainnya. Dari hasil peningkatan produksi tersebut akan terjadi pula peningkatan pendapatan petani dalam usahatani bawang merah yang mengikuti SL-GAP.

Hasil penelitian ini sesuai dengan beberapa penelitian diantaranya oleh [13] dan [14] menunjukkan bukti empiris bahwa sekolah lapang memberikan pengaruh positif dan signifikan terhadap peningkatan produktivitas petani.

\section{KESIMPULAN REKOMENDASI Kesimpulan}

Pelaksanaan SL - GAP budidaya bawang merah di Desa Sekoto Kecamatan Badas Kabupaten Kediri telah menunjukkan efektif dan efisiennya terhadap peningkatan produksi dan bawang merah sebesar 48,58 \% dan meningkatkan pendapatan petani sebesar $25 \%$. Hasil penelitian menunjukkan perbedaan yang signifikan antara produksi dan pendapatan petani bawang merah yang telah mengikuti dan tidak mengikuti SL - GAP. 


\section{Rekomendasi}

Petani seharusnya meninggalkan cara lama dan menerapkan teknologi usahatani sesuai dengan teknologi yang di gunakan dalam kegiatan SL-GAP karena telah memberikan peningkatan produksi dan pendapatan.

\section{DAFTAR PUSTAKA}

[1] Direktorat Perbenihan Hortikultura. 2011. Pedoman Pemurnian Varietas Bawang Merah. Kementerian Pertanian. Jakarta

[2] Badan Pusat Statistik. 2014. Statistik Sayuran dan Buah-Buahan Semusim Indonesia. BPS Pusat. Jakarta (ID).

[3] BPS Propinsi Jawa Timur (2018). Analisis Produksi Bawang Merah. BPS Jawa Timur - Surabaya.

[4] Bank Indonesia. 2013. Produksi Buah dan sayur semusim. Bank Indonesia. Jakarta

[5] Siagian, VJ. 2016. Oulook Bawang Merah. Pusat Data dan Informasi Pertanian. Kementerian Pertanian. Jakarta.

[6] Siagian, VJ. 2015. Oulook Bawang Merah. Pusat Data dan Informasi Pertanian. Kementerian Pertanian. Jakarta.

[7] Pusat Kebijakan Perdagangan Dalam Negeri. 2014. Analisis Outlook Pangan 2015-2019. Badan Pengkajian
Dan Pengembangan Kebijakan Perdagangan Kementerian Perdagangan. Jakarta.

[8] BPS Provinsi Jawa Timur. 2015. Luas Panen Sayuran dan buah semusim di Jawa Timur tahun 2008 - 2017. BPS Jatim. Surabaya.

[9] BPS Kabupaten Kediri. 2014. Kediri Recency in Ficure. Katalog BPS 1102001.3506.

http://kedirikab.bps.go.id

[10] Samuelson, PA, Nordhaus, WD. 2004. Ilmu Makroekonomi.Jakarta: PT. Media Global Edukasi.

[11] Mosher, AT, 1984. Menggerakan dan Membangun Pertanian, CV. Jasa Guna, Jakarta

[12] Leuwis, Cees. 2009. Komunikasi Untuk Inovasi Pedesaan. New York Press. New York. Hal. 664.

[13] Siti Aisyah dan Dinar. 2016. Peranan Penyuluhan Pertanian Terhadap Penerapan Sistem Tanam Jajar Legowo ( Suatu Kasus Pada Kelompok Tani di Kecamatan Cigasong Kabupaten Majalengka) : 181-195

[14] Nursyamsi, S, Soetoro T, Hardiyanto 2017. Dampak Sekolah Lapangan Pengeloaan Tanamn Terpadu (SLPTT) Terhadap Penerapan Teknologi PTT Usaha Tani Padi Sawah. Agroinfo Galuh 4 [3] 